AGRITECH, Vol. 37, No. 3, Agustus 2017, Hal. 334-342 DOI: http://doi.org/10.22146/agritech.10446 ISSN 0216-0455 (Print), ISSN 2527-3825 (Online) Tersedia online di https://jurnal.ugm.ac.id/agritech/

\title{
Pengaruh Penambahan Maltodekstrin dan Suhu Inlet Spray Dryer terhadap Karakteristik Fisiko-Kimia Bubuk Sari Kerandang (Canavalia virosa)
}

\author{
The Effect of Maltodextrin and Spray Dryer Inlet Temperature on Physico-Chemical Characteristic of Kerandang
}

(Canavalia virosa) Milk Powder

\author{
Titiek Farianti Djaafar ${ }^{1 *}$, Umar Santoso², Anggara Ariestyanta ${ }^{3}$ \\ ${ }^{1}$ Balai Pengkajian Teknologi Pertanian Yogyakarta,Jl. Stadion Maguwoharjo 22, Sleman Yogyakarta 55584, Indonesia \\ ${ }^{2}$ Departemen Teknologi Pangan dan Hasil Pertanian, Fakultas Teknologi Pertanian, Universitas Gadjah Mada, \\ Jl. Flora No. 1, Bulaksumur, Yogyakarta 55281, Indonesia \\ ${ }^{3}$ Dinas Perikanan Kabupaten Kulon Progo, Jl. Sugiman 21, Kulon Progo Yogyakarta 55652, Indonesia \\ Email: titiekfd@yahoo.co.id
}

Submisi: 1 Maret 2016; Penerimaan: 14 September 2016

\begin{abstract}
ABSTRAK
Kerandang (Canavalia virosa) dapat dijumpai di sepanjang lahan pasir pantai di Kabupaten Kulonprogo dan Bantul, Yogyakarta. Biji kerandang dapat diolah menjadi sari kerandang seperti halnya kedelai, sebagai bentuk diversifikasi produk. Penelitian ini bertujuan untuk mengetahui karakteristik fisik dan kimia bubuk sari kerandang. Biji kerandang kupas (tanpa kulit ari) diolah menjadi sari kerandang dengan perbandingan biji dan air 1:8 (b/v). Penambahan maltodekstrin sebanyak $0 \% ; 5 \% ; 7,5 \%$; dan $10 \%(\mathrm{~b} / \mathrm{v})$ padasari kerandang, kemudian dikeringkan menggunakan spray dryer dengan suhu inlet $80^{\circ} \mathrm{C} ; 100^{\circ} \mathrm{C}$; dan $120^{\circ} \mathrm{C}$. Analisis yang dilakukan meliputi kadar air, bulk density, kelarutan, water holding capacity (WHC), fat holding capasity (FHC), protein terlarut, total fenolik, genistein, dan aktivitas antioksidan. Percobaan dilakukan menggunakan rancangan acak lengkap dengan ulangan percobaan sebanyak tiga kali. Hasil penelitian menunjukkan bahwa kemampuan menahan air (WHC) bubuk sari kerandang berkisar antara 2,98\%-64,55\%. Konsentrasi suhu inlet dan maltodekstrin serta interaksi keduanya memberikan perbedaan nyata terhadap WHC bubuk sari kerandang. FHC bubuk sari kerandang (108,89\%-262,25\%) mengalami peningkatan dengan bertambahnya konsentrasi maltodekstrin dan temperatur inlet spray dryer. Bulk density bubuk sari kerandang berkisar antara $0,34 \mathrm{~g} / \mathrm{mL}-0,58 \mathrm{~g} / \mathrm{mL}$. Kelarutan bubuk sari kerandang di berbagai $\mathrm{pH}$ berhubungan erat dengan kandungan protein dalam bubuk sari kerandang. Protein terlarut bubuk sari kerandang menurun dengan semakin meningkatnya konsentrasi maltodekstrin dan temperatur inlet. Total fenolik bubuk sari kerandang berkisar antara 1,33 g GAE/100 g-7,55 g GAE/100 g. Aktivitas antioksidan bubuk sari kerandang berkisar antara 9,61\%-74,87\%.
\end{abstract}

Kata kunci: Karakteristik; bubuk sari kerandang; fisiko-kimia

\begin{abstract}
Kerandang (Canavalia virosa) can be found in sandy beaches in Kulon Progo and Bantul Regency, Yogyakarta. The kerandang seeds can be processed into kerandang milk such as soybean, as one form of product diversification. The objective of this study was to know the physicochemical characteristics of the kerandang milk powder. Peeled kerandang seeds were processed into kerandang milk with seed water ratio of 1:8 (w/v). The addition of maltodekstrin $(0 \%, 5 \%, 7.5 \%$ and $10 \%(\mathrm{w} / \mathrm{v}))$ into kerandang milk, then dried using a spray dryer with inlet temperature of $80{ }^{\circ} \mathrm{C}$; $100{ }^{\circ} \mathrm{C}$, and $120^{\circ} \mathrm{C}$. Analyses were conducted on the water content, bulk density, solubility, water holding capacity
\end{abstract}


(WHC), fat holding capasity (FHC), soluble protein, total phenolic, genistein, and antioxidant activity. This study was conducted using acompletely randomized design with three replications. The results of this study showed that Water Holding Capacity of kerandang milk ranged of 2,98\% to $64,55 \%$. Inlet temperature, maltodextrin concentration and interaction of these two factors gave significant effects on the WHC of kerandang milk powder. FHC of kerandang milk powder increased (108.89\%-262.25\%) with the higher concentration of maltodextrin and spray inlet temperature. The bulk density of kerandang milk powder was between $0.34 \mathrm{~g} / \mathrm{mL}-0.58 \mathrm{~g} / \mathrm{mL}$. Kerandang milk powder solubility at various $\mathrm{pH}$ was closely related tot he protein content in milk powder kerandang. The dissolved protein content of kerandang milk powder decreased with the increased of maltodextrin concentration and inlet temperature. The content of total phenolic of kerandang milk powder ranged from $1.33 \mathrm{gGAE} / 100 \mathrm{~g}$ to $7.55 \mathrm{gGAE} / 100 \mathrm{~g}$. The antioxidant activity of the kerandang milk ranged between $9.61 \%$ to $74.87 \%$.

Keywords: Characteristic; kerandang milk powder; physico-chemical

\section{PENDAHULUAN}

Kabupaten Bantul dan Kulon Progo memiliki lahan pasir pantai dengan luas lahan 3000 ha, tumbuh tanaman legume (kacang-kacangan) yang menjalar dan oleh masyarakat setempat disebut Kerandang (Canavalia virosa). Budidaya tanaman kerandang pada lahan-lahan pasir pantai sangat bermanfaat karena adanya bakteri pada akar tanaman ini yang dapat mengikat nitrogen dari udara sehingga dapat memperbaiki kesuburan tanah.

Tanaman kerandang tergolong leguminosa, menghasilkan polong yang berukuran antara $10-15 \mathrm{~cm}$, berisi 4-8 biji yang berwarna coklat, dengan panjang biji 14,27 mm dan lebar 9,81 mm (Eke dkk., 2007: Djaafar dkk., 2010). Kandungan protein biji kerandang cukup tinggi $(37,30$ $\%$ wb) (Djaafar dkk., 2010), hampir sama dengan kedelai dan sedikit lebih tinggi dibanding Canavalia virosa yang berasal dari Peninsular, India (31,3\%) (Thangadurai dkk., 2001). Kandungan protein dalam biji Canavalia berkisar antara 22,4\%-24,9\%, bahkan Canavalia gladiata yang berwarna kulit coklat memiliki kandungan total protein berkisar antara 26,8\%-35\% (Sridhardan Seena, 2006).

Pemanfaatan biji kerandang hingga saat ini belum dilakukan secara optimal, terutama dalam bentuk produk yang bernilai ekonomi tinggi dan memberikan aspek kesehatan bagi tubuh. Pemanfaatan biji kerandang yang sudah dilakukan oleh masyarakat disekitar lahan pasir pantai Kabupaten Kulon Progo diantaranya adalah sebagai bahan baku dalam pembuatan tempe dan tahu (Djaafar dan Siswanto, 2009). Pemanfaatan biji kerandang dapat dilakukan secara optimal dengan diversifikasi produk yaitu pengolahan biji kerandang menjadi bubuk sari kerandang dengan metode spray drying.

Bahan makanan yang mengandung komponen fenolik yang rentan terhadap kerusakan akibat panas seperti isoflavon (genistein, Daidzein dan glisitein) dapat diawetkan dengan teknologi spray drying. Wagner dan Warthesen (1995) mengemukakan bahwa penggunaan spray drying dalam pengolahan sari wortel berhasil diaplikasikan dan dapat mempertahankan stabilitas senyawa karotenoid. Menurut Sousa dkk. (2008), penggunaan spray drying dalam pengolahan bubuk sari tomat, juga dapat mempertahankan warna bubuk tomat.

Pada proses spray drying memerlukan bahan pengisi. Ada beberapa bahan pengisi, namun yang umum digunakan adalah maltodekstrin karena lebih ekonomis dan tersedia di pasaran. Penggunaan bahan pengisi maltodekstrin menghasilkan bubuk yang memiliki sifat fisik baik dan maltodekstrin berfungsi sebagai agen enkapsulasi (encapsulating agent) pada peningkatan stabilitas senyawa polifenol bahan pangan (Tuyen dkk., 2010).

Senyawa isoflavon merupakan senyawa yang ada dalam golongan leguminosa atau kacang-kacangan, berfungsi sebagai antioksidan, yaitu isoflavon (daizein, genistein dan glisitein) (Pyo dkk., 2005; Ding dan Shah, 2010). Senyawa genistein atau 4',5,7-trihidroksiisoflavon merupakan bentuk aglikon dari genistin berbentuk kristal padat berwarna kuning yang tidak larut dalam air tetapi larut dalam etanol atau metanol. Rumus molekul dari genistein adalah $\mathrm{C}_{15} \mathrm{H}_{10} \mathrm{O}_{5}$ dan berat molekul 270 daltons dengan titik leleh 200-202 ${ }^{\circ} \mathrm{C}$ (Albulescu dan Popovici, 2007). Senyawa genistein memiliki tiga gugus hidroksil (Gambar 1) sehingga bersifat lebih hidrofobik dan memiliki efek terapetik yang lebih baik dibanding jenis isoflavon daidzein (Albulescu dan Popovici, 2007).

Senyawa antioksidan merupakan senyawa yang dapat mencegah terjadinya reaksi radikal bebas dan mencegah reaksi autooksidasi pada bahan yang mengandung lemak (Aini dkk., 2006). Senyawa tersebut dapat mencegah kerusakan sel pada

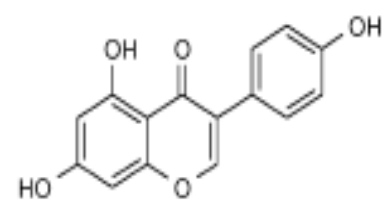

Gambar 1. Struktur senyawa genistein (Sumber : Albulescu dan Popovici, 2007) 
makhluk hidup yang disebabkan oleh reactive oxygen species (ROS) atau stres oksidatif yang tidak terkontrol. Penangkapan radikal bebas (radical scavenging)atau pengikatan ion metal merupakan suatu aktivitas antioksidan (Perron dan Brumaghim, 2009). Antioksidan alami banyak dijumpai dalam bahan makanan seperti buah, sayur, maupun kacangkacangan. Senyawa-senyawa polifenol seperti flavonol, flavon, isoflavon, flavanon, antosianidin dan flavanol merupakan senyawa antioksidan alami yang dapat dijumpai dalam bahan makanan (Han dkk., 2007). Berdasarkan uraian tersebut, maka dalam penelitian ini dilakukan penelitian tentang karakter fisik dan kimia bubuk sari kerandang dengan cara proses spray drying menggunakan bahan pengisi maltodekstrin serta aktivitas antioksidannya.

\section{METODE PENELITIAN}

\section{Bahan Penelitian}

Biji kerandang sebagai bahan baku dalam penelitian ini diperoleh dari lahan pasir pantai Desa Bugel, Kecamatan Panjatan, Kabupaten Kulon Progo. Bahan-bahan pendukung yang digunakan adalah maltodekstrin dan bahan-bahan kimia untuk analisis.

\section{Metode Penelitian}

Ada dua tahap penelitian yang dilaksanakan, yaitu preparasi biji kerandang dan pembuatan bubuk sari kerandang.

\section{Preparasi Biji Kerandang}

Polong kerandang dengan ketuaan optimum, dipecah secara manual untuk mengeluarkan biji kerandang. Sortasi dilakukan secara manual untuk memisahkan yang tua dan muda. Biji kerandang dengan kulit ari berwarna coklat gelap dan kadar air berkisar antara 15-18\% yang digunakan dalam pengolahan sari kerandang. Selanjutnya biji dikeringkan hingga kadar air mencapai $\pm 10 \%$ kemudian dilakukan pengupasan kulit ari biji kerandang. Pengupasan kulit ari biji kerandang dengan kadar air $\pm 10 \%$ dilakukan menggunakan alat pengupas dengan sistem abrasive sehingga diperoleh biji kerandang yang berwarna kekuningan.

Analisis kimiawi yang dilakukan terhadap biji kerandang yaitu pengujian total fenolik dengan metode Folin-Ciocalteau (Radix dkk., 2009), aktifitas antioksidan (Radical Scavenging Activity) dilakukan dengan metode DPPH (Pyo dkk., 2005; Xu dan Chang, 2007; Wang dkk., 2009). Pengukuran RSA juga dilakukan pada vitamin C 300 ppm dan Asam Galat 300 ppm sebagai kontrol positif dan analisis kandungan isoflavon genistein dengan HPLC (Georgetti dkk., 2007).

\section{Pengolahan Bubuk Sari Kerandang}

Pengolahan sari kerandang (Vongsawasdi dkk., 2003)

Pengolahan sari kerandang dilakukan berdasarkan metode yang diampaikan oleh Vongsawasdi dkk. (2003) dengan sedikit modifikasi. Pertama-tama dilakukan perendaman $100 \mathrm{~g}$ biji kerandang yang telah dikupas dalam air selama 18 jam (perbandingan air dan biji = 10:1 (v/b)), setiap 3 jam dilakukan penggantian air. Selanjutnya dilakukan penggilingan/pengecilan ukuran biji kerandang dengan penambahan air panas menggunakan blender. Perbandingan biji kerandang dan air panas adalah 1:8 (v/b). Suspensi yang dihasilkan, disaring menggunakan kain saring dan dihasilkan sari kerandang.

\section{Pengolahan bubuk sari kerandang dengan spray dryer}

Pengolahan bubuk sari kerandang dilakukan dengan variasi bahan pengisi maltodekstrin sebanyak $0 ; 5 ; 7,5 ; 10 \%$ (b/v). Pengolahan bubuk sari kerandang dengan spray dryer menggunakan variasi suhu inlet $80,100,120{ }^{\circ} \mathrm{C}$ dan suhu outlet spray drying berkisar antara $60^{\circ} \mathrm{C}-80^{\circ} \mathrm{C}$.

\section{Analisis karakteristik fisiko kimia bubuk sari kerandang}

Analisis karakteristik fisiko kimia bubuk sari kerandang meliputi kadar air (AOAC, 1990), bulk density (Jinapong dkk., 2008), kelarutan bubuk sari kerandang dalam berbagai variasi $\mathrm{pH}$ (Sudarmadji, 1996), water holding capacity (WHC) (Sosulski, 1976), dan fat holding capacity (FHC) (Sosulski, 1976), total fenolik dengan metode Folin-Ciocalteau (Radix dkk., 2009), aktivitas antioksidan bubuk sari kerandang dengan metode DPPH (Pyo dkk., 2005; Xu dan Chang, 2007; Wang dkk., 2009), isoflavon Genistein dengan HPLC (Georgetti dkk., 2007), protein larut air (Lowry dkk., 1951).

\section{Rancangan Percobaan}

Rancangan penelitian acak lengkap faktorial dengan ulangan sebanyak 3 kali digunakan dalam penelitian ini. Faktor pertama (A) adalah variasi penambahan maltodekstrin dengan 4 taraf yaitu konsentrasi $0 \%$ (b/v) A0; konsentrasi 5\% (b/v) A1; konsentrasi 7,5\% (b/v) A2 dan konsentrasi 10\% (b/v) A3. Faktor kedua (B) adalah suhu inlet spray dryer dengan tiga taraf, yaitu B1 (suhu inlet $80^{\circ} \mathrm{C}$ ); B2 (suhu inlet $100^{\circ} \mathrm{C}$ ) dan B3 (suhu inlet $120^{\circ} \mathrm{C}$ ).

Analysis of varians (ANOVA) pada tingkat kepercayaan 95\% digunakan untuk menguji data yang diperoleh. Uji lanjut dengan DMRT (Duncan Multiple Range Test) dilakukan apabila ANOVA menunjukkan perbedaan nyata antar perlakuan. Data yang diperoleh dianalisa denganprogram Statistic Analysis Program (SAS) Ver. 9. 


\section{HASIL DAN PEMBAHASAN}

\section{Kandungan Total Fenolik, Genistein, dan Aktivitas Antioksidan Biji Kerandang}

Kandungan total fenolik biji kerandang sebesar 3,61 $\pm 0,20 \%$ (g GAE $/ 100 \mathrm{~g}$ ). Biji kerandang mengandung total fenolik yang lebih tinggi dibanding biji Canavalia yang ada di India, yaitu Canavalia gladiata (0,22 g GAE/100 g) dan Canavalia ensiformis (0,24 g GAE/100 g) (Doss dkk., 2010). Dengan demikian, biji kerandang berpotensi sebagai bahan pangan sumber antioksidan. Hal yang sama juga dikemukan oleh Lin dkk. (2006) bahwa komponen fenolik dari kedelai dan produk-produk olahan kedelai berperan sebagai antioksidan.

Biji kerandang mengandung genistein sebesar 3,23\%. Genistein yang merupakan salah satu jenis isoflavon yang telah banyak diketahui terdapat dalam biji kedelai. Aktivitas antioksidan biji kerandang yang dinyatakan dengan kemampuannya untuk menangkap radikal bebas (Radical Scavenging Activity) DPPH sebesar 10,86\%. Menurut Doss dkk. (2010), radical scavenging activity dari Canavalia gladiata sebesar 19,36\% dan Canavalia ensiformis sebesar $33,48 \%$.

\section{Karakteristik Fisik Bubuk Sari kerandang}

\section{Kadar air}

Kadar air bubuk sari kerandang berkisar antara 4,63\% sampai 11,35\% (Gambar 2). Bubuk sari kerandang yang dihasilkan dari pengolahan pada suhu inlet spray $120{ }^{\circ} \mathrm{C}$ dan tanpa penambahan maltodekstrin memiliki kadar air terendah. Sedangkan kadar air tertinggi terdapat pada perlakuan suhu inlet spray $80^{\circ} \mathrm{C}$ dengan konsentrasi maltodekstrin $10 \%(\mathrm{~b} / \mathrm{v})$.

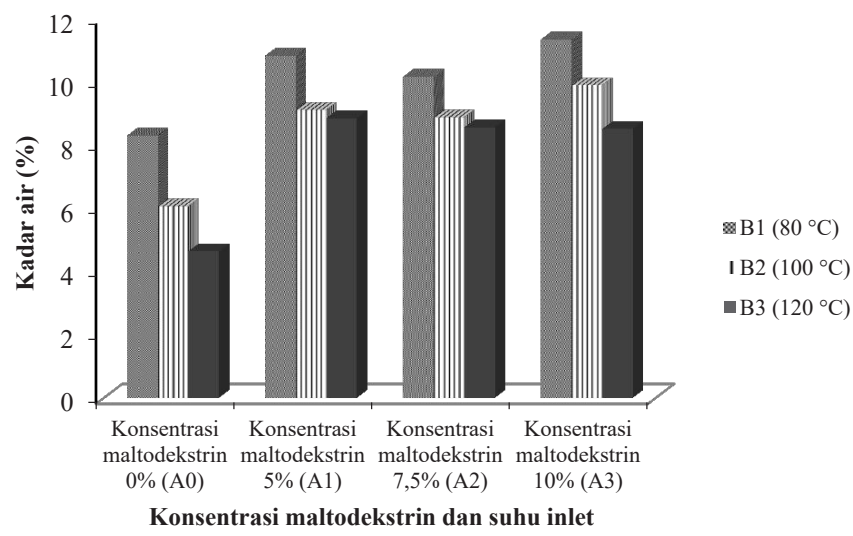

Gambar 2. Kadar air bubuk sari kerandang dengan pengolahan menggunakan spray dryer pada perlakuan suhu inlet $(80,100$, dan $\left.120^{\circ} \mathrm{C}\right)$ dan konsentrasi maltodekstrin $(0 \%, 5 \%, 7,5 \%$, dan $10 \%(\mathrm{~b} / \mathrm{v}))$
Tabel 1. Feeding rate dan yield sampel bubuk sari kerandang yang dihasilkan selama proses spray drying

\begin{tabular}{ccccccc}
\hline Suhu inlet & \multicolumn{2}{c}{$80{ }^{\circ} \mathrm{C}$} & \multicolumn{2}{c}{$100{ }^{\circ} \mathrm{C}$} & \multicolumn{2}{c}{$120{ }^{\circ} \mathrm{C}$} \\
\hline $\begin{array}{c}\text { Konsentrasi } \\
\text { maltodekstrin }\end{array}$ & $\begin{array}{c}\text { Feeding } \\
\text { rate } \\
(\mathrm{mL} / \\
\text { menit) }\end{array}$ & $\begin{array}{c}\text { Yield } \\
(\mathrm{g})\end{array}$ & $\begin{array}{c}\text { Feeding } \\
\text { rate }(\mathrm{mL} / \\
\text { menit })\end{array}$ & $\begin{array}{c}\text { Yield } \\
(\mathrm{g})\end{array}$ & $\begin{array}{c}\text { Feeding } \\
\text { rate } \\
(\mathrm{mL} / \\
\text { menit })\end{array}$ & $\begin{array}{c}\text { Yield } \\
(\mathrm{g})\end{array}$ \\
\hline $0 \%$ & 4,85 & 12,56 & 6,56 & 14,52 & 6,67 & 18,29 \\
$5 \%$ & 4,76 & 36,75 & 6,15 & 39,25 & 6,40 & 39,97 \\
$7,5 \%$ & 4,57 & 36,25 & 5,76 & 38,87 & 5,93 & 39,73 \\
$10 \%$ & 4,26 & 38,63 & 5,16 & 39,77 & 5,44 & 42,75 \\
\hline
\end{tabular}

Perlakuan suhu inlet, konsentrasi maltodekstrin serta interaksi antara suhu inlet dengan konsentrasi maltodekstrin memberikan perbedaan yang nyata terhadap kadar air bubuk sari kerandang pada taraf uji 5\%. Menurut Tonon dkk. (2008), pada suhu inlet yang tinggi terdapat gradien panas yang tinggi antara atomized feed dan udara pengering (drying air) yang mengakibatkan cepatnya proses evaporasi air pada bahan yang di-spray sehingga menghasilkan bubuk dengan kadar air rendah. Hal yang sama juga dikemukakan oleh Quek dkk. (2007) pada penelitiannya tentang bubuk sari semangka, Chegini dan Ghobadian (2005) pada bubuk sari jeruk, Goula dkk. (2004) tentang bubuk saritomat dan Hernandez dkk. (2005) pada bubuk cactus pear.

Penurunan kadar air terjadi dengan meningkatnya konsentrasi maltodekstrin hanya berlaku pada konsentrasi 5\% hingga 7,5\%. Pada konsentrasi 0\% ke 5\% dan konsentrasi $7,5 \%$ ke $10 \%$ terjadi peningkatan kadar air, hal ini sangat berkaitan dengan drying rate pada saat proses spray drying dimana total padatan yang terdapat dalam sari kerandang cair berbeda karena adanya penambahan maltodekstrin dengan konsentrasi yang berbeda $(0 \% ; 5 \% ; 7,5 \%$; dan $10 \%)$. Waktu proses pembentukan bubuk (yield produk) dipengaruhi oleh total padatan pada masing-masing perlakuan. Semakin banyak konsentrasi maltodekstrin yang ditambahkan, maka semakin lama waktu proses pembentukkan bubuk (yield). Pada Tabel 1 disajikan data rerata feeding rate dan yield bubuk sari kerandang.

\section{Water Holding Capacity (WHC)}

Kapasitas menahan air atau Water holding capacity bubuk sari kerandang berkisar antara 2,98\% hingga 64,55\%. Kapasitas menahan air (WHC) terendah terdapat pada perlakuan suhu inlet spray $120{ }^{\circ} \mathrm{C}$ dengan konsentrasi maltodekstrin $10 \%$ sedangkan $\mathrm{WHC}$ tertinggi terdapat pada perlakuan suhu inlet spray $120^{\circ} \mathrm{C}$ tanpa penambahan maltodekstrin. Konsentrasi maltodekstrin, suhu inlet serta interaksi diantara keduanya memberikan perbedaan yang nyata (taraf uji 5\%) terhadap kapasitas menahan air bubuk sari kerandang (Gambar 3). 


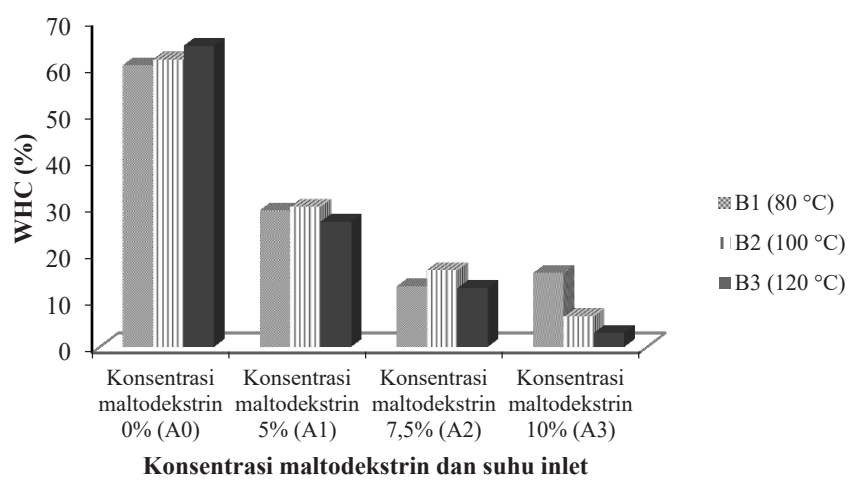

Gambar 3. Water Holding Capacity (WHC) bubuk sari kerandang pada berbagai perlakuan suhu inlet $\left(80,100\right.$, dan $\left.120{ }^{\circ} \mathrm{C}\right)$ dan konsentrasi maltodekstrin $(0 \%, 5 \%, 7,5 \%$, dan $10 \%)$ spray dryer.

Suhu inlet yang semakin meningkat dan semakin tinggi konsentrasi maltodekstrin menyebabkan terjadi penurunan kapasitas pengikatan air (water holding capacity) bubuk sari kerandang. Hal tersebut berkaitan erat dengan sifat maltodekstrin yang memiliki higroskopisitas rendah (Hernandez dkk., 2005) dan rusaknya struktur jaringan fenolik antar gugus fenolik dengan maltodekstrin. Rusaknya struktur jaringan tersebutmenyebabkan kemampuan mengikat air bubuk sari kerandang menjadi menurun. Hal yang sama juga dikemukakan oleh Vega-Gálvez (2009) berdasarkan hasil penelitiannya yaitu pengaruh suhu pengeringan pada pengolahan bubuk lada merah (Capsicum annuum, L. var. Hungarian).

Pada saat proses spray drying maka akan terbentuk gel dan kemudian membentuk jaringan tiga dimensi yang dapat memerangkap air. Dengan meningkatnya konsentrasi maltodekstrin dalam pengolahan bubuk sari, maka jaringan tiga dimensi yang terbentuk semakin banyak sehingga mengurangi kemampuan untuk memerangkap air dari bubuk sari kerandang yang dihasilkan. Dengan demikian, semakin besar konsentrasi maltodekstrin yang ditambahkan, maka nilai WHC bubuk sari kerandang semakin menurun.

\section{Fat Holding Capacity (FHC)}

Fat holding capacity bubuk sari kerandang mengalami peningkatan baik pada perlakuan suhu maupun konsentrasi maltodekstrin. Semakin tinggi perlakuan suhu maka FHC makin meningkat. Begitu pula pada konsentrasi maltodekstrin yang tinggi maka FHC makin meningkat.

Fat holding capacity (FHC) sari kerandang berkisar antara $108,89 \%$ (suhu inlet spray $80{ }^{\circ} \mathrm{C}$ dengan konsentrasi maltodekstrin 0\%) hingga 262,25\% (suhu inlet spray 120 ${ }^{\circ} \mathrm{C}$ dengan konsentrasi maltodekstrin 10\%) (Gambar 4). Berdasarkan uji ANOVA FHC bubuk sari kerandang diperoleh hasil bahwa perlakuan suhu inlet spray drying, konsentrasi

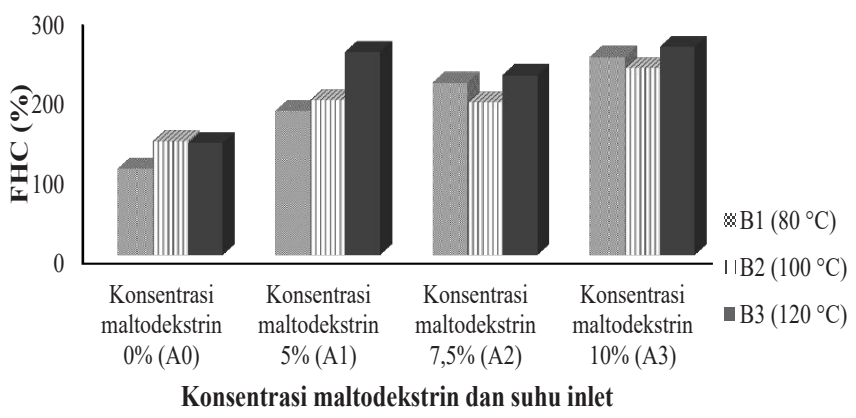

Gambar 4. Fat holding capacity bubuk sari kerandang pada berbagai perlakuan suhu inlet $\left(80,100\right.$, dan $\left.120^{\circ} \mathrm{C}\right)$ dan konsentrasi maltodekstrin $(0 \%, 5 \%, 7,5 \%$, dan $10 \%)$ spray dryer

maltodekstrin serta interaksi antara suhu inlet dan konsentrasi maltodekstrin menunjukkan perbedaan yang nyata pada taraf uji $5 \%$.

Meningkatnya persentase $\mathrm{FHC}$ ini disebabkan oleh adanya ikatan dari gugus-gugus maltodekstrin dan kandungan asam amino non polar (glisin, alanin, valin, leusin, isoleusin, dan prolin) bubuk sari kerandang yang berikatan dengan rantai hidrokarbon dari minyak, sehingga menyebabkan pengikatannya terhadap minyak menjadi meningkat (Sathe dkk., 1982 dalam Kaur dan Singh, 2006).

\section{Bulk Density}

Keruahan atau bulk density didefinisikan sebagai banyaknya massa bahan per satuan volume tertentu. Bulk density mengindikasikan kerapatan antar partikel bubuk sari kerandang yang dihasilkan dari pengolahan dengan spray drying. Bulk density bubuk sari kerandang berkisar antara $0,34 \mathrm{~g} / \mathrm{mL}$ (suhu inlet spray $120{ }^{\circ} \mathrm{C}$ dengan konsentrasi maltodekstrin $10 \%$ ) hingga $0,58 \mathrm{~g} / \mathrm{mL}$ (suhu inlet spray $80^{\circ} \mathrm{C}$ dengan konsentrasi maltodekstrin 0\%) (Gambar 5). Perlakuan suhu inlet dan konsentrasi maltodekstrin serta interaksi

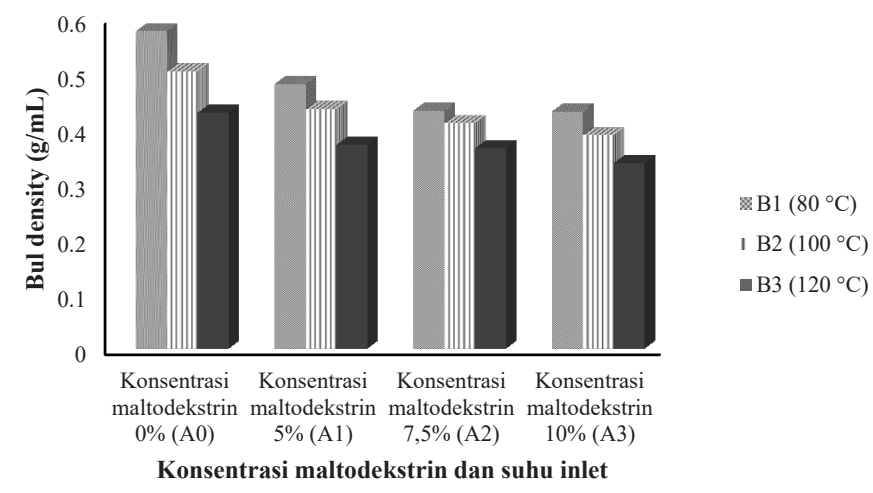

Gambar 5. Bulk density bubuk sari kerandang pada berbagai perlakuan suhu inlet $\left(80,100\right.$, dan $\left.120{ }^{\circ} \mathrm{C}\right)$ dan konsentrasi maltodekstrin $(0 \%, 5 \%, 7,5 \%$, dan $10 \%)$ spray dryer. 
diantara keduanya berpengaruh nyata terhadap bulk density bubuk sari kerandang menunjukkan perbedaan yang nyata pada taraf uji 5\% berdasarkan uji ANOVA.

Peningkatan suhu inlet akan meningkatkan keruahan (bulky) bubuk sari kerandang. Hal ini disebabkan oleh semakin tingginya suhu inlet pada proses spray drying maka partikel bubuk yang terbentuk semakin ringan dan kadar airnya menurun sehingga menyebabkan porositas intragranular bubuk sari kerandang menjadi tinggi. Tuyen dkk., (2010), menjelaskan bahwa bulk density bubuk buah Gac (Momordica cochichinensis) hasil spray drying sangat dipengaruhi oleh suhu inlet (suhu pengeringan) dengan taraf uji 1\%. Menurunnya densitas keruahan bubuk sari kerandang disebabkan oleh penyusutan ukuran droplet bubuk sebagai akibat dari semakin tingginya suhu sehingga proses penguapan air juga tinggi.

\section{Kelarutan Bubuk Sari Kerandang dalam Berbagai Variasi pH}

Kelarutan bubuk sari kerandang berkaitan erat dengan kandungan protein dalam bubuk sari kerandang. Hal ini berhubungan dengan pencapaian titik isoelektrik dari protein. Pengaruh suhu inlet dan konsentrasi maltodekstrin terhadap persentase kelarutan bubuk sari kerandang dalam berbagai variasi $\mathrm{pH}$ dapat dilihat pada Tabel 2 dan kandungan protein terlarut $(\% \mathrm{db})$ bubuk sari kerandang pada berbagai variasi suhu inlet dan konsetrasi maltodekstrin disajikan dalam Tabel 3.

Semakin bertambahnya $\mathrm{pH}$ (menuju suasana basa/ alkali), maka tingkat kelarutan bubuk sari kerandang semakin tinggi. Hal ini berlaku pada bubuk sari kerandang dengan variasi suhu inlet $\left(80^{\circ} \mathrm{C}, 100^{\circ} \mathrm{C}\right.$, dan $\left.120^{\circ} \mathrm{C}\right)$ maupun variasi konsentrasi maltodekstrin $(0 \%, 5 \%, 7,5 \%$, dan $10 \%)$.

Tabel 2. Pengaruh suhu inlet dan konsentrasi maltodekstrin terhadap persentase kelarutan bubuk sari kerandang dalam berbagai variasi $\mathrm{pH}$

\begin{tabular}{|c|c|c|c|c|c|c|}
\hline \multirow{2}{*}{ Komponen } & \multicolumn{6}{|c|}{ Kelarutan (\%) } \\
\hline & pH 2 & $\mathrm{pH} 4$ & pH 6 & $\mathrm{pH} 8$ & $\mathrm{pH} 10$ & $\mathrm{pH} 12$ \\
\hline \multicolumn{7}{|l|}{$\begin{array}{l}\text { Konsentrasi } \\
\text { maltodekstrin }\end{array}$} \\
\hline $0 \%$ & $62,34^{d}$ & $77,66^{\mathrm{d}}$ & $78,58^{\mathrm{d}}$ & $78,24^{\mathrm{d}}$ & $78,02^{\mathrm{c}}$ & $81,88^{\mathrm{d}}$ \\
\hline $5 \%$ & $81,95^{\mathrm{c}}$ & $90,05^{\mathrm{c}}$ & $91,27^{\mathrm{c}}$ & $91,46^{\mathrm{c}}$ & $91,40^{\mathrm{b}}$ & $95,28^{\mathrm{b}}$ \\
\hline $7,5 \%$ & $85,05^{\mathrm{b}}$ & $93,11^{\mathrm{a}}$ & $92,38^{\mathrm{b}}$ & $92,92^{\mathrm{b}}$ & $93,04^{\mathrm{a}}$ & $95,60^{\mathrm{a}}$ \\
\hline $10 \%$ & $85,57^{\text {a }}$ & $92,86^{\mathrm{b}}$ & $93,45^{\mathrm{a}}$ & $94,07^{\mathrm{a}}$ & $92,97^{\mathrm{a}}$ & $94,80^{\mathrm{c}}$ \\
\hline \multicolumn{7}{|l|}{ Suhu inlet } \\
\hline $80^{\circ} \mathrm{C}$ & $78,96^{\mathrm{a}}$ & $89,18^{\mathrm{a}}$ & $89,49^{\mathrm{a}}$ & $89,61^{\mathrm{a}}$ & $88,97^{\mathrm{a}}$ & $92,27^{\mathrm{a}}$ \\
\hline $100^{\circ} \mathrm{C}$ & $78,72^{\mathrm{b}}$ & $87,83^{\mathrm{c}}$ & $88,52^{\mathrm{c}}$ & $89,27^{\mathrm{b}}$ & $88,62^{\mathrm{b}}$ & $91,92^{\mathrm{b}}$ \\
\hline $120^{\circ} \mathrm{C}$ & $78,51^{\mathrm{c}}$ & $88,25^{\mathrm{b}}$ & $88,76^{\mathrm{b}}$ & $88,65^{\mathrm{c}}$ & $88,99^{\mathrm{a}}$ & $91,49^{\circ}$ \\
\hline \multicolumn{7}{|l|}{ Signifikasi interaksi } \\
\hline $\begin{array}{l}\text { - Suhu inlet spray } \\
\text { dryer }\end{array}$ & $*$ & $*$ & $*$ & $*$ & NS & $*$ \\
\hline $\begin{array}{l}\text { Konsentrasi } \\
\text { maltodekstrin }\end{array}$ & $*$ & $*$ & $*$ & $*$ & $*$ & $*$ \\
\hline - Konsentrasi x suhu & $*$ & $*$ & $*$ & $*$ & NS & $*$ \\
\hline
\end{tabular}

Keterangan: Angka yang diikuti dengan huruf yang berbeda berarti berbeda nyata

* menandakan berbeda nyata pada taraf uji $\mathrm{p}=0,05, \mathrm{NS}$ : tidak signifikan

Tabel 3. Protein larut air bubuk sari kerandang

\begin{tabular}{cccc}
\hline \multirow{2}{*}{$\begin{array}{c}\text { Konsentrasi } \\
\text { maltodekstrin }\end{array}$} & \multicolumn{3}{c}{ Protein larut air (\%) } \\
\cline { 2 - 4 } & $80{ }^{\circ} \mathrm{C}$ & $100{ }^{\circ} \mathrm{C}$ & $120^{\circ} \mathrm{C}$ \\
\cline { 2 - 4 } $0 \%$ & 41,19 & 40,65 & 39,27 \\
$5 \%$ & 23,86 & 23,12 & 21,33 \\
$7,5 \%$ & 19,27 & 18,77 & 16,93 \\
$10 \%$ & 16,65 & 16,21 & 16,08 \\
\hline
\end{tabular}

Kelarutan bubuk sari kerandang semua perlakuan sampel terendah terjadi pada $\mathrm{pH}$ 2. Hal ini menunjukkan bahwa protein bubuk sari kerandang secara alamiah bersifat asam dan titik isoelektrik protein biji kerandang berada pada pH 2. Damodaran (1997) mengemukakan bahwa kelarutan minimal terjadi pada saat protein mencapai titik isoelektriknya dan pada umumnya protein dalam bahan pangan bersifat asam, sehingga kelarutan maksimum berada pada $\mathrm{pH}$ basa/ alkali.

\section{Karakteristik Kimia Bubuk Sari Kerandang}

\section{Total Fenolik}

Total fenolik bubuk sari kerandang berkisar antara $1,33 \pm 0,19$ (suhu inlet $120^{\circ} \mathrm{C}$ dan konsentrasi maltodekstrin $10 \%$ ) hingga $7,55 \pm 0,17 \%$ (suhu inlet $80{ }^{\circ} \mathrm{C}$, konsentrasi maltodekstrin 0\%) (g GAE/100g) (Gambar 6). Suhu yang tinggi $\left(120{ }^{\circ} \mathrm{C}\right)$ dapat mengakibatkan rusaknya gugus fungsional fenolik yang ada pada bubuk sari kerandang. Georgetti dkk. (2007), menyampaikan bahwa meningkatnya suhu spray drying (suhu inlet) berperanan pada penurunan kandungan genistein dan total fenolikekstrak kedelai.

Perlakuan suhu inlet, konsentrasi maltodekstrin dan interaksi antara keduanya menunjukkan perbedaan yang nyata terhadap total fenolik bubuk sari kerandang pada taraf uji 5\%. Makin meningkat suhu inlet maka total fenolik bubuk sari kerandang makin rendah. Hal yang sama juga terjadi pada perlakuan konsentrasi maltodektrin. Konsentrasi maltodekstrin yang meningkat mengakibatkan kandungan total fenolik pada bubuk sari kerandang menjadi berkurang. Pemanasan (perebusan) dapat menyebabkan degradasi polifenol dan pelepasan komponen fenolik, sehingga selama proses pengolahan terutama pemanasan akan terjadi penurunan kandungan fenolik pada bahan makanan. Hal yang sama juga dikemukan oleh Xu dan Chang (2008), 


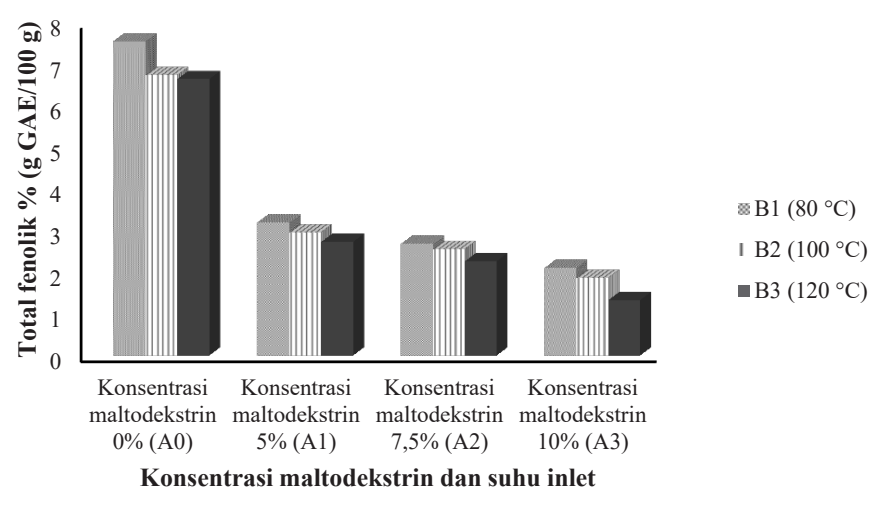

Gambar 6. Kandungan total fenol \% (gGAE /100 g) sari kerandang pada perlakuan suhu inlet $\left(80,100\right.$, dan $\left.120^{\circ} \mathrm{C}\right)$ dan konsentrasi maltodekstrin $(0 \%, 5 \%, 7,5 \%$, dan $10 \%)$.

bahwa proses perebusan pinto beans dapat menyebabkan terjadi penurunan kandungan total fenolik sekitar 63 - 77\% sedangkan untuk black beans penurunan total fenolik sekitar $61-74 \%$.

\section{Aktivitas Antioksidan Bubuk Sari Kerandang}

Persentase penangkapan radikal (Radical Scavenging Activity/RSA) menunjukkan kemampuan menangkap radikal DPPH dari suatu bahan. Persentase penangkapan radikal yang semakin besar, menandakan bahwa aktivitas antioksidannya semakin tinggi, yang ditunjukkan dengan menurunnya absorbansi larutan DPPH pada sampel yang diuji. Persentase Radical Scavenging Activity bubuk sari kerandang berkisar antara 9,61 $\pm 0,08 \%$ (perlakuan suhu inlet 120 dan konsentrasi maltodekstrin 7,5\%) hingga 74,87 $\pm 0,17 \%$ (perlakuan suhu inlet 80 dan konsentrasi maltodekstrin 0\%). Perlakuan suhu inlet, konsentrasi maltodekstrin serta interaksi antara keduanya memberikan perbedaan yang nyata pada taraf uji $5 \%$ berdasarkan uji ANOVA.

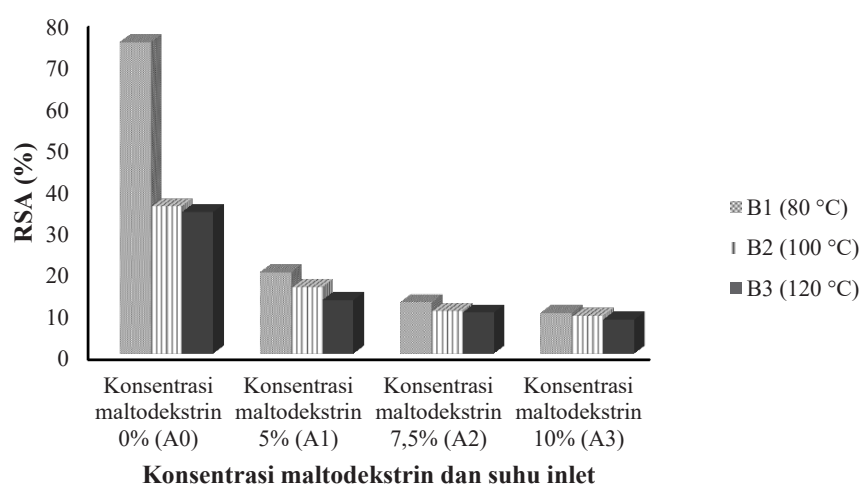

Gambar 7. Aktivitas antioksidan (\% Radical Scavenging Activity) bubuk sari kerandang pada perlakuan suhu inlet $\left(80,100\right.$, dan $\left.120^{\circ} \mathrm{C}\right)$ dan konsentrasi maltodekstrin $(0 \%, 5 \%, 7,5 \%$, dan $10 \%)$ spray dryer.
Peningkatan suhu inlet menyebabkan persentase Radical Scavenging Activity bubuk sari kerandang mengalami penurunan,akibat terjadi degradasi komponen antioksidan dalam bubuk sari kerandang yang berkaitan dengan adanya reaksi oksidasi atau dekomposisi senyawa tersebutkarena adanyainduksi panas (Georgetti dkk., 2007 dan Tuyen, 2010). Degradasi gugus reaktif antioksidan menyebabkan berkurangnya donor hidrogen kepada radikal DPPH yang ditunjukkan dengan penurunan aktivitas antioksidan bubuk sari kerandang pada perlakuan suhu inlet yang semakin tinggi (Gambar 7).

Senyawa fenolik merupakan senyawa antioksidan yang penting karena mempunyai gugus hidroksil pada cincin A dan atau $\mathrm{B}$ yang mampu mendonasikan hidrogen ke radikal bebas sehingga memberikan kontribusi terhadap penangkapan radikal (Rostagno dkk., 2003). Aktivitas antioksidan senyawa fenolik terutama isoflavon berkaitan erat dengan jumlah dan posisi gugus hidroksilnya. Evans dkk. dalam Georgetti dkk. mengemukakan bahwa polifenol berpotensi mendonorkan hidrogen kepada radikal DPPH untuk mencapai bentuk idealnya. Penjelasan yang dikemukakan tersebut menguatkan bukti bahwa bubuk sari kerandang yang mengandung komponen fenolik mempunyai potensi sebagai antioksidan, karena mampu mendonorkan gugus hidroksil pada radikal DPPH. Nilai Radical Scavenging Activity atau kemampuan mendonorkan gugus hidroksil bubuk sari kerandang tidak hanya dipengaruhi oleh kuantitas total fenolik, tetapi juga kualitas komponen polifenolnya yang terkait dengan jumlah dan posisi gugus hidroksil dalam struktur senyawa penyusunnya.

\section{Kandungan Genistein Bubuk Sari Kerandang}

Analisis kandungan genistein hanya dilakukan pada perlakuan suhu inlet $80^{\circ} \mathrm{C}$, konsentrasi maltodekstrin $0 \%$ dan perlakuan suhu inlet $120{ }^{\circ} \mathrm{C}$, konsentrasi maltodekstrin $0 \%$. Pemilihan sampel yang diinjeksikan ke HPLC berdasarkan dari sedikitnya terjadi kerusakan total fenolik serta sampel

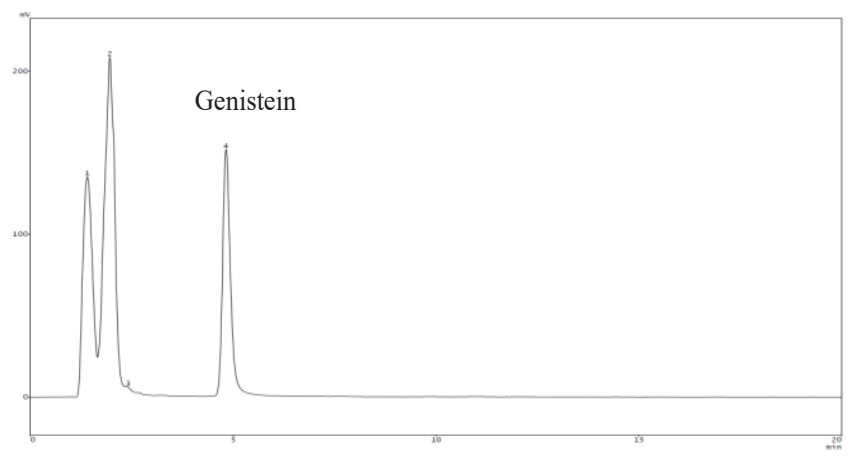

Gambar 8. Kromatogram bubuk sari kerandang pada perlakuan suhu inlet $80{ }^{\circ} \mathrm{C}$, konsentrasi maltodekstrin $0 \%$, peak keempat (genistein) dengan waktu retensi 4,820 menit 


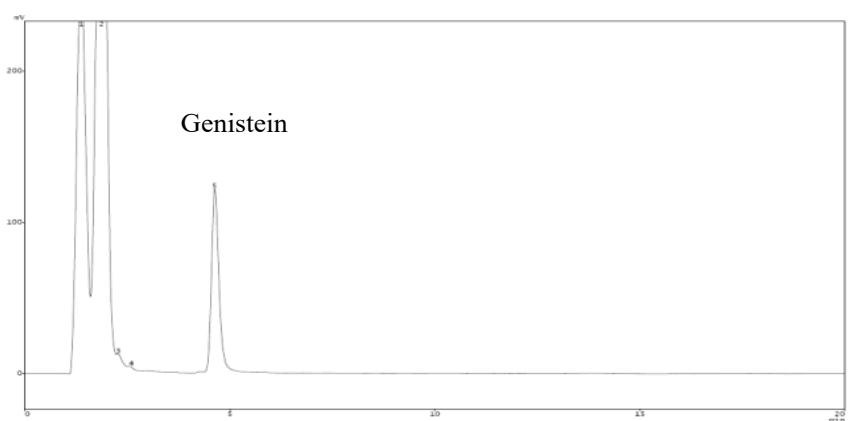

Gambar 9. Kromatogram bubuk sari kerandang pada perlakuan suhu inlet $120{ }^{\circ} \mathrm{C}$, konsentrasi maltodekstrin $0 \%$, peak kelima (genistein) dengan waktu retensi 4,645 menit

Tabel 4. Kandungan genistein bubuk sari kerandang

\begin{tabular}{lc}
\hline \multicolumn{1}{c}{ Perlakuan } & $\begin{array}{c}\text { Genistein } \\
(\mathrm{g} / 100 \mathrm{~g})\end{array}$ \\
\hline $\begin{array}{l}\text { Bubuk sari kerandang dengan suhu inlet } \\
80{ }^{\circ} \mathrm{C} \text {, konsentrasi maltodekstrin } 0 \%\end{array}$ & 0,61 \\
Bubuk sari kerandang dengan suhu inlet & \\
$120^{\circ} \mathrm{C}$, konsentrasi maltodekstrin $0 \%$ & 0,45 \\
\hline
\end{tabular}

yang diduga terjadi kerusakan akibat pengaruh suhu saat spray dryer (tanpa penambahan maltodekstin). Kromatogram injeksi bubuk sari kerandang dengan konsentrasi maltodekstrin $0 \%$ dan suhu inlet $80{ }^{\circ} \mathrm{Cserta}$ bubuk sari kerandang dengan konsentrasi maltodekstrin $0 \%$ dan suhu inlet $120{ }^{\circ} \mathrm{Cdisajikan}$ dalam Gambar 8 dan Gambar 9.

Kromatogam pada Gambar 9 menunjukkan bahwa bubuk sari kerandang (Canavalia virosa) memiliki kandungan isoflavon genistein yang memiliki sifat sebagai antioksidan. Genistein ditemukan pada bubuk sari kerandang hasil spray drying pada perlakuan suhu inlet $80{ }^{\circ} \mathrm{C}$, konsentrasi maltodekstrin $0 \%$ dan perlakuan suhu inlet 120 ${ }^{\circ} \mathrm{C}$, konsentrasi maltodekstrin 0\% (Tabel 4).

Pada saat suhu inlet spray dryer meningkat, menyebabkan kandungan isoflavon genistein bubuk sari kerandang mengalami penurunan. Suhu inlet $120{ }^{\circ} \mathrm{C}$ dapat merusak gugus fungsional isoflavon yang ada pada bubuk sari kerandang sehingga kandungan genistein menurun.

\section{KESIMPULAN}

Berdasarkan penelitian yang dilakukan, maka dapat disimpulkan bahwa biji kerandang sebagai sumber protein dengan kandungan protein sebesar 37,30\%, mengandung total fenolik sebesar 3,61\% (g GAE/100 g), isoflavon genistein sebesar 3,23\% (g/100 g) dan memiliki persentase radical scavenging activity (RSA) sebesar 10,86\%. Bubuk sari kerandang memiliki kandungan protein larut air sebesar
16,08\%-41,19\%. Perlakuan suhu inlet spray drying dan konsentrasi maltodekstrin berpengaruh nyata terhadap kadar air, water holding capacity (WHC), fat holding capacity (FHC), bulk density, total fenol, dan radical scavenging activity (RSA) bubuk sari kerandang. Sedangkan suhu inlet spray drying yang tinggi dapat menurunkan kandungan genistein pada bubuk sari kerandang dan mengakibatkan aktivitas antioksidannya menurun. Bubuk sari kerandang dengan kualitas yang baik dapat dihasilkan melalui proses menggunakan spray drying pada suhu inlet $80-100^{\circ} \mathrm{C}$ dan tanpa penambahan maltodekstrin.

\section{DAFTAR PUSTAKA}

Aini, N., Purwono, B.dan Tahir, I. (2006). Structure - antioxidant activities relationship analysis of isoeugenol, eugenol, vanilin and their derivatives. Indoesian Journal of Chemistry 7(1): 61-66.

Albulescu, M. dan Popovici, M. (2007). Isoflavonesbiochemistry, pharmacology and therapeutic use. Reveu Roumaine de Chimie 52(6): 537-550.

Anonim, (1990). Official Methods of Analysis of the Association of Official Analytical Chemists (AOAC). Vol I, Published by AOAC International, Arlington, USA.

Chegini, G.R. dan Ghobadian, B.(2005). Effect of spray drying conditions on physical properties of orange juice powder. Drying Technology 23(3): 657-668.

Damodaran, S. (1997). Food proteins: An overview. Dalam: Damodaran,S. dan Paraf,A. (Eds.), Food Proteins and Their Applications(pp. 1-21). Marcel Dekker, New York.

Ding, W.K. dan Shah, N.P. (2010). Enhancing the biotransformation of isoflavones in soymilk supplemented with lactose using probiotic bacteria during extended fermentation. Journal of Food Science 75(3): M140-M149.

Djaafar, T.F. dan Siswanto (2009). Kerandang, tanaman lahan pasir alternative pengganti kedelai. Laporan singkat kegiatan penelitian SINTA, 2009. Tidak dipublikasikan.

Djaafar, T.F., Cahyaningrum, N. dan Purwaningsih, H.(2010). Physico-chemical characteristics of tribal beans (Canavalia virosa) and its alternative tofu and tempeh food products. International Journal of Agricultural Science 11(2): 74-80.

Doss, A., Pugalenthi, M., Rajendrakumaran, D. dan Vadivel, V. (2010). Phenols, flavonoids and antioxidant activity of underutilized legume seeds. Asian Journal Experimental Biological Science 1(3): 700-705.

Eke, C.N.U., Asoegwu,S.N. dan Nwandikom, G.I. (2007). Some physical properties of Jackbean seed (Canavalia 
ensiformis). Agricultural Engineering International: The CIGR Ejournal ManuscriptFP 07 0149: 1-11.

Foti, M., Piatell, Baratta, M.T. dan Roberto, G.(1996). Flavonoid, courmains and cinnamic acid as antioxidant in a micellar system. structure activity relationship. Journal of Agricultural Food Chemistry 44: 497-501.

Georgetti, S.R., Casagrande, R., Souza, C.R.F., Oliveira, W.P. dan Fonseca, M.J.V. (2007). Spray drying of the soybean extract: effects on chemical properties and antioxidant activity. LWT-Food Science and Technology 41(8): 1521-1527.

Goula, A.M., Adamopoulus, K.G. dan Kazakis, N.A. (2004). Influence of spray drying conditions on tomato powder properies. Journal of Drying Technology 22(5): 11291151.

Han, X., Shen T. dan Lou, H. (2007). Dietary polyphenols and their biological significance. International Journal of Molecular Science 8(9): 950-988.

Hernandez, Rodriguez, G.R., Gonzalez-Garcia, R., GrajalesLagunes, A. dan Ruiz-Cabrera, M.A. (2005). Spray drying of cactus pear juice (Opuntia streptacantha): effect on psysicochemical properties of powder and reconstituted product. Drying Technology 23(4): 955973.

Jinapong, N., Suphantharika, M. dan Jamnong, P. (2008). Production of instant soymilk powders by ultrafiltration, spray drying and fluidized bed agglomeration. Journal of Food Engineering 84(2): 194-205.

Lin, C.H., Wei,Y.T. dan Chou, C.C. (2006). Enhanced antioxidative activity of soybean koji prepared with various filamentous fungi. Journal of Food Microbiology 23(7): 628-633.

Lowry, O.H., Rosenbrough, N.J., Farr, A.L. dan Randall, R.J. (1951). Protein measurement with folin phenol reagent. Journal of Biological Chemistry 193: 265-275.

Prakash, A. (2001). Antioxidant Activity. Medallion Laboratories Analytical Progress. Minnesota, USA 19 (2): $1-4$.

Pyo, Y.H., Lee, T.C.dan Lee, Y.C. (2005). Effect of lactic acid fermentation on enrichment of antioxidant properties and bioactive isoflavones in soybean. Journal of Food Science 70(3): S215-S220.

Radix A.I., Astuti, M., Santoso, U. Dan Prihati, S.N. (2009). In vitro antioxidant activity of anthocyanins of black soybean seed coat in human low density lipoprotein (LDL). Food Chemistry 112(3): 659-663.
Rostagno, M.A., Palma M. dan Barroso, C.G. (2003). Ultrasound assisted extraction of soy isoflavones. Journal of Chromatography Analysis 1012(2): 119-128.

Sridhar, K.R. dan Seena, S.(2006). Nutritional and antinutritional significance of four unconventional legumes of the genus canavalia - a comparative study. Food Chemistry 99(2): 267-288.

Sosulski, F.W., Humbert, E.S., Bui, K. dan Jones, J.D. (1976). Functional properties of represeed fluors, concentrates and isolates. Journal of Food Science 41: 1349.

Sousa, A.S., Borges, S.V., Magalhães, N.F., Ricardo, H.V. dan Azevedo, A.D. (2008). Spray-dried tomato powder: reconstitution properties and colour. Brazilian Archives of Biology and Technology 51(4): 807-814.

Sudarmaji, S. (1996). Teknik Analisa Biokimiawi. Penerbit Liberty, Yogyakarta.

Thangadurai, D., Viswanathan,N. dan Ramesh (2001). The chemical composition and nutritional evaluation of Canavalia virosa: a wild perennial bean from Eastern Ghats of Peninsular India. European Food Research and Technology 213(6): 456-459.

Tonon, V., Renata, Brabet, C., Miriam D. dan Hubinger (2008). Influence of proces conditions on the physicochemical properties of acai (Euterpe oleraceae Mart.) powder produced by spray drying. Journal of Food Engineering 88: 411-418.

Tuyen, C., Kha, M.H., Nguyen, Paul, D. dan Roach (2010). Effect of spray drying conditions on the physicochemical and antioxidant properties of the gac (Momordica cochichinensis) fruit aril powder. Journal of Food Engineering 98(3): 385-392.

Vega, G., Antonio, Karina, D.S., Rodríguez, K., Lemus, M.R., Miranda, M., López, J. dan Perez, W.M. (2009). Effect of air-drying temperature on physico-chemical properties, antioxidant capacity, colour and total phenolic content of red pepper (Capsicum annuum, L. var. Hungarian). Food Chemistry 117(4): 647-653.

Wagner, L.A. dan Warthesen, J.J. (1995). Stability of spray dried encapsulated carrot carotenes. Journal of Food Science 60(5): 1048-1053.

Wang, T., Jónsdóttir, R.G. dan Ólafsdóttir (2009). Total phenolic compounds, radical scavenging and metal chelation of extracts from Icelandic seaweeds. Food Chemistry 116(1): 240-248.

Xu, B.J. dan Chang, S.K.C. (2007). A comparative study on phenolic profiles and antioxidant activities of legumes as affected by extraction solvents. Journal of Food Science 72(2): S159-S166. 